\title{
Unexpected Coordination of Aminoiminophosphoranate Ligands with Alkali Metals
}

\author{
Alexander Steiner and Dietmar Stalke \\ Institut für Anorganische Chemie der Universität Göttingen, Tammannstrasse 4, \\ W-3400 Göttingen, Germany
}

Received September 17, 1992

\begin{abstract}
The crystal structures of the derivatives $\left[\mathrm{Ph}_{2} \mathrm{P}\left(\mathrm{Me}_{3} \mathrm{SiN}\right)_{2} \mathrm{Li}(\mathrm{THF})_{2}\right],{ }^{1}\left[\mathrm{Na}(\mathrm{THF})_{6}\right]\left[\mathrm{Na}\left\{(\mathrm{NSiMe})_{2} \mathrm{PPh}_{2}\right\}_{2}\right]$, $\left[\mathrm{Ph}_{2} \mathrm{P}\left(\mathrm{Me}_{3} \mathrm{SiN}\right)_{2} \mathrm{~K}(\mathrm{THF})_{4}\right],\left[\mathrm{Ph}_{2} \mathrm{P}\left(\mathrm{Me}_{3} \mathrm{SiN}\right)_{2} \mathrm{Rb}(\mathrm{THF})\right]_{2}$, and $\left[\mathrm{Ph}_{2} \mathrm{P}\left(\mathrm{Me}_{3} \mathrm{SiN}\right)_{2} \mathrm{Cs}\right]_{2, \infty}$ have been determined by low-temperature $\mathrm{X}$-ray structure analysis. The lithium and the potassium compounds form monomeric structures, whereas the sodium derivative forms a previously unheard of sodium-sodiumate structure, where one sodium is surrounded by two anions and the other by six THF molecules. The rubidium and the cesium derivatives adopt a stair-shaped dimeric structure. In the latter, a very close intramolecular metal- $\pi$ system contact is observed. A long-range intermolecular metal- $\pi$ system contact binds the dimers in an overall polymeric area, resulting in molecular rods.
\end{abstract}

\section{Introduction}

Chelating ligands are of basic interest in both heterocycle and coordination chemistry. One of the most fruitful systems has been the [R-N-E-N-R]- ligand coordinating with two nitrogen atoms. Substituents of frequent use are $[R-N-C(R)-N-R]^{-2,-6}$ $\left[\mathrm{R}-\mathrm{N}-\mathrm{Si}(\mathrm{R})_{2}-\mathrm{O}-\mathrm{R}\right]^{-, 7,8}$ and $[\mathrm{R}-\mathrm{N}-\mathrm{S}(\mathrm{R})-\mathrm{N}-\mathrm{R}]^{-.9,10}$ The preparation of compounds containing these chelates normally involves the lighter alkali metal precursors. The lithium and sodium aminoiminophosphoranates $\left[\mathrm{R}-\mathrm{N}-\mathrm{P}(\mathrm{R})_{2}-\mathrm{N}-\mathrm{R}\right] \mathrm{M}(\mathrm{M}=\mathrm{Li}, \mathrm{Na})$ were prepared previously, ${ }^{11-13}$ but their structures have remained unknown. We synthesized all alkali metal derivatives to study the coordination of the aminoiminophosphoranate ligand. The low-temperature X-ray structures of $\mathrm{Ph}_{2} \mathrm{P}\left(\mathrm{Me}_{3} \mathrm{SiN}\right)_{2} \mathrm{M}$ where $\mathrm{M}=\mathrm{Li}(1), \mathrm{Na}(2), \mathrm{K}(3), \mathrm{Rb}(4)$, and $\mathrm{Cs}(5)$ are presented.

\section{Results and Discussion}

Preparation of 1-5. Diphenyl((trimethylsilyl)amino)((trimethylsilyl)imino)phosphorane reacts in THF with butyllithium (1), sodium hydride (2), potassium hydride (3), rubidium metal (4) and cesium metal (5) to give the alkali metal derivatives in quantitative yields. Filtration and recrystallization from THF
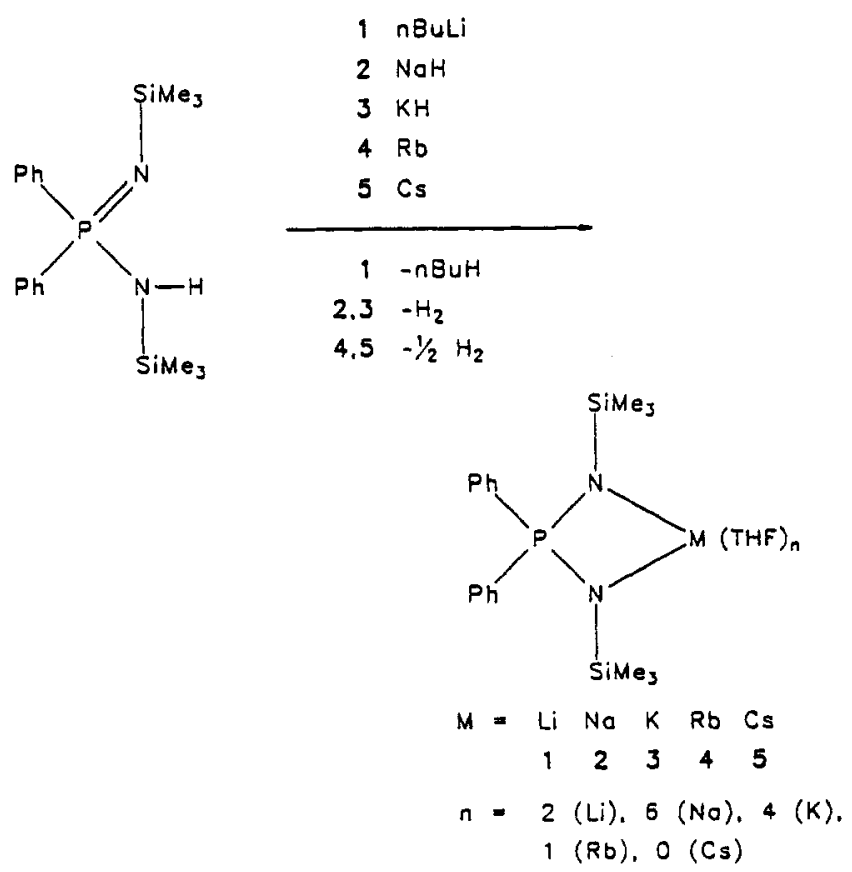

$0020-1669 / 93 / 1332-1977 \$ 04.00 / 0$ at $-35^{\circ} \mathrm{C}$ give colorless low-melting crystals. The sodium and potassium compounds $(2,3)$ lose their coordinated THF molecules in vacuum completely, whereas in the lithium (1) and rubidium (4) derivative this coordination is stable. The cesium metal in 5 is not coordinated by THF at all, even though the synthesis and crystallization were carried out in this solvent. The structures and chemistry of the sulfinamidinato alkali metal compounds $\mathrm{PhS}\left(\mathrm{Me}_{3} \mathrm{SiN}\right)_{2} \mathrm{M}(\mathrm{M}=$ alkali metal) were probed by us recently, and these studies have revealed three classes of structures $\mathbf{a - c .} .^{9,10}$

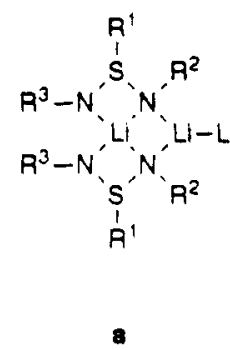

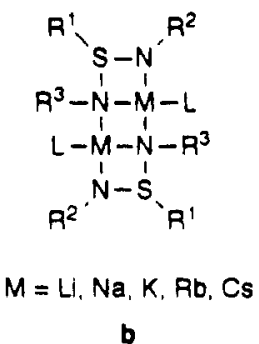<smiles>[R7]N([R])[AlH]N([R7])[SiH]([R7])N([R7])[R]</smiles>

In a, two $\mathrm{SN}_{2} \mathrm{Li}$ four-membered rings are placed on adjacent sides of the central $\mathrm{Li}_{2} \mathrm{~N}_{2}$ four-membered ring, which results in a twisted tricyclic structure with $C_{2}$ symmetry. In $\mathrm{b}$, the two $\mathrm{SN}_{2} \mathrm{Li}$ four-membered rings are fused on opposite sides of the central $\mathrm{M}_{2} \mathrm{~N}_{2}$ four-membered ring. Both, the stair-shaped tricyclic structure in $\mathbf{b}$ and the eight-membered ring in $\mathbf{c}$ adopt $C_{i}$ symmetry. Furthermore, we isolated and identified the "ate" type derivative $\left[\mathrm{Li}\left(12-\right.\right.$ crown-4 $\left.\left._{2}\right]\left[\mathrm{Li}\left(\mathrm{NSiMe}_{3}\right)_{2} \mathrm{SPh}\right\}_{2}\right]$ by X-ray structure analysis and ${ }^{7} \mathrm{Li}$ solid state NMR. ${ }^{14}$

(1) Recknagel, A.; Steiner, A.; Noltemeyer, M.; Brooker, S.; Stalke, D.; Edelmann, F. T. J. Organomet. Chem. 1991, 414, 327.

(2) Stalke, D.; Wedler, M.; Edelmann, F. T. J. Organomet. Chem. 1992. $431, \mathrm{C} 1$.

(3) Hey, E.; Ergezinger, C.; Dehnicke, K. Z. Naturforsch. 1984, 44B, 205.

(4) Fenske, D.; Hartmann, E.; Dehnicke, K. Z. Naturforsch. 1988, 43B, 1611.

(5) Ergezinger, C.; Weller, F.; Dehnicke, K. Z. Naturforsch. 1988, 43B, 1621

(6) Maier, S.; Hiller, W.; Străhle, J.; Ergezinger, C.; Dehnicke, K. Z. Naturforsch. 1988, 43B, 1628

(7) Veith, M.; Böhnlein, J. Chem. Ber. 1989, 122, 603.

(8) Veith, M.; Böhnlein, J.; Huch, V. Chem. Ber. 1989, 122, 841

(9) Pauer, F.; Stalke, D. J. Organomet. Chem. 1991, 418, 127.

(10) Edelmann, F. T.; Knösel, F.; Pauer, F.; Stalke, D.; Bauer, W. J. Organomet. Chem., in press.

(11) Schmidbaur, H.; Schwirten, K.; Pickel, H. Chem. Ber. 1969, 102, 564.

(12) Wolfsberger, W.; Hager, W. Z. Anorg. Allg. Chem. 1976, 425, 169.

(13) Wolfsberger, W.; Hager, W. Z. Anorg. Allg. Chem. 1977, 433, 247.

(14) Pauer, F.; Rocha, J.; Stalke, D. J. Chem. Soc., Chem. Commun. 1991, 1477.

(c) 1993 American Chemical Society 


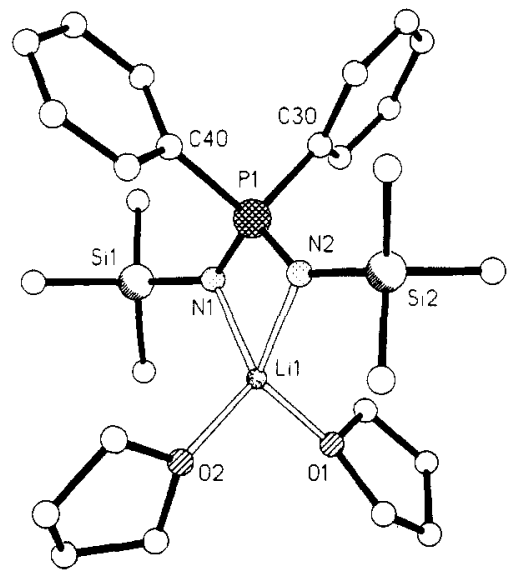

Figure 1. Structure of 1 in the solid state.
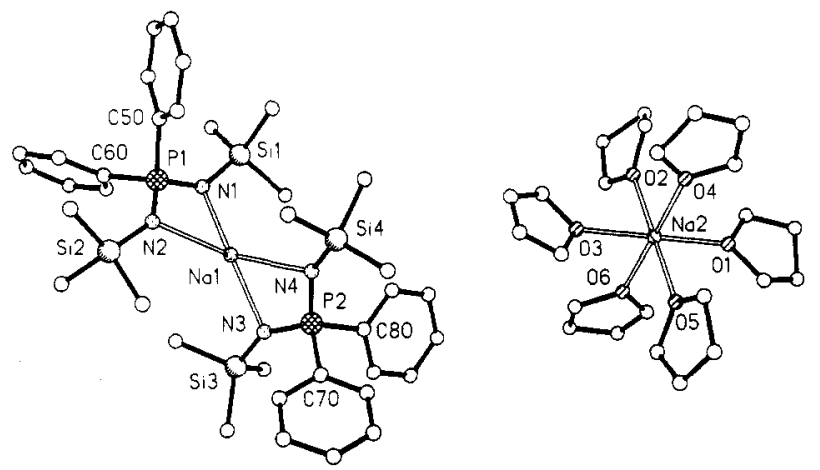

Figure 2. Structure of 2 in the solid state. Two uncoordinated THF molecules have been omitted for clarity.

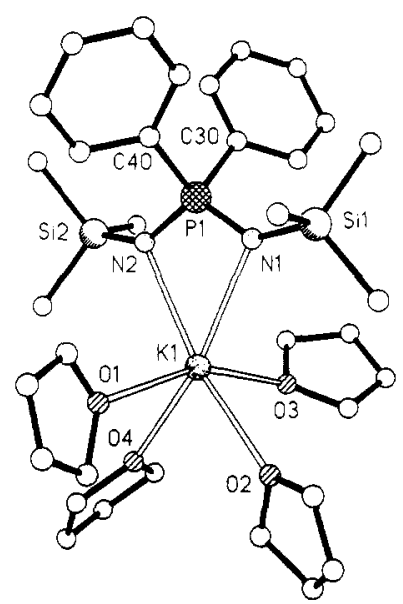

Figure 3. Structure of $\mathbf{3}$ in the solid state.

The experiments reported in this paper have been carried out to investigate whether or not the results for the $\mathrm{PhS}\left(\mathrm{Me}_{3} \mathrm{SiN}\right)_{2} \mathrm{M}$ system are directly transferable to the $\mathrm{Ph}_{2} \mathrm{P}\left(\mathrm{Me}_{3} \mathrm{SiN}\right)_{2} \mathrm{M}(\mathrm{M}=$ alkali metal) system. Our investigations show that they are not. The derivatives $\left[\mathrm{Ph}_{2} \mathrm{P}\left(\mathrm{Me}_{3} \mathrm{SiN}\right)_{2} \mathrm{Li}(\mathrm{THF})_{2}\right]$ (1) and $\left[\mathrm{Ph}_{2} \mathrm{P}\right.$ $\left.\left(\mathrm{Me}_{3} \mathrm{SiN}\right)_{2} \mathrm{~K}(\mathrm{THF})_{4}\right]$ (3) are monomers in the solid state (Figures 1 and 3 ). The sodium derivative $\left[\mathrm{Na}(\mathrm{THF})_{6}\right][\mathrm{Na}$ \{(NSiMe $\left.\left.\left.)_{2}\right)_{2} \mathrm{Ph}_{2}\right\}_{2}\right](2)$ is, to our knowledge, the first sodiumsodiumate structure (Figure 2). Only two other structures with a $\mathrm{Na}$ (THF $)_{6}{ }^{+}$cation are known. ${ }^{15,16}$ In the structure of the cryptobase-stabilized sodium electride $\mathrm{Na}$ - is the counterion. ${ }^{17}$ The two heavier derivatives $\left[\mathrm{Ph}_{2} \mathrm{P}\left(\mathrm{Me}_{3} \mathrm{SiN}\right)_{2} \mathrm{Rb}(\mathrm{THF})\right]_{2}$ (4) (Figure 4) and $\left[\mathrm{Ph}_{2} \mathrm{P}\left(\mathrm{Me}_{3} \mathrm{SiN}\right)_{2} \mathrm{Cs}\right]_{2, \infty}(\mathbf{5})$ (Figure 5), however,

(15) Schumann, H.; Genthe, W.; Hahn, E.; Hossain, M. B.; van der Helm, D. J. Organomet. Chem. 1986, 299, 67.

(16) Chen, M.; Wu, G.; Wu, W.; Zhuang, S.; Huang, Z. Organometallics $1988,7,802$.

(17) Tehan, F. J.; Barnett, B. L.; Dye, J. L. J. Am. Chem. Soc. 1974, 96, 7204

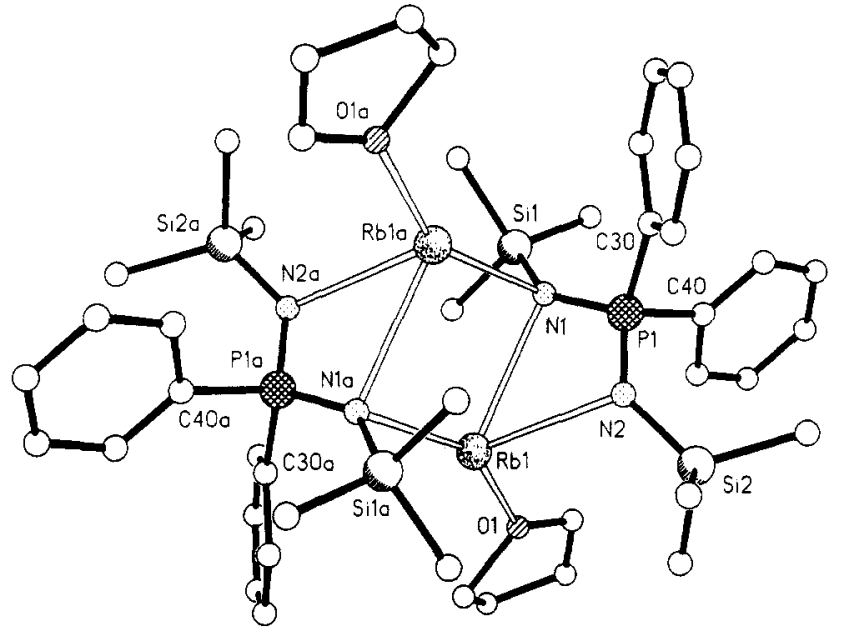

Figure 4. Structure of 4 in the solid state.

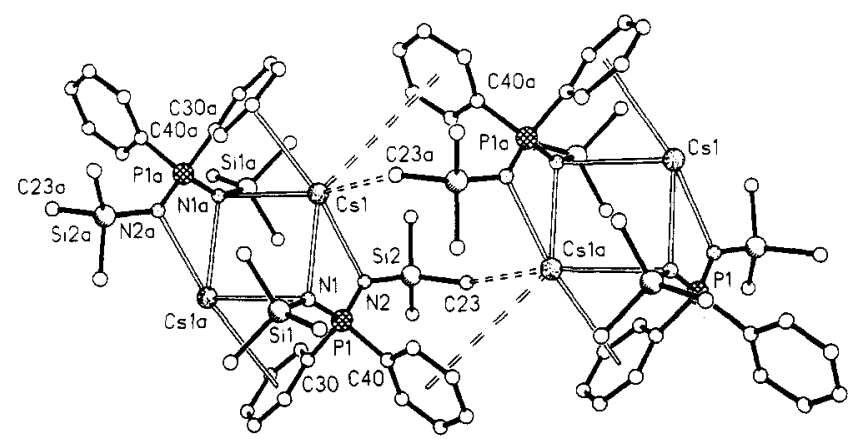

Figure 5. Structure of 5 in the solid state. Two dimers have been depicted to elucidate the polymerization.

are closely related to the structural class $\mathbf{b}$, mentioned earlier. The cesium cation in $\mathbf{5}$ forms a remarkably close intramolecular and a weak intermolecular contact to a phenyl ligand, resulting in infinite molecular rods.

Crystal Structures of 1-5. The structures of the lithium aminoiminophosphoranate 1 and the potassium aminoiminophosphoranate 3 are monomeric in the solid state. The anion is chelating both metals, resulting in four-membered kite-shaped $\mathrm{PN}_{2} \mathrm{Li}$ (Figure 1) and $\mathrm{PN}_{2} \mathrm{~K}$ (Figure 3) rings. The two $\mathrm{P}-\mathrm{N}$ bonds (average $158 \mathrm{pm}$ in 1 and $157 \mathrm{pm}$ in 3) and two metal-N bonds (average $206 \mathrm{pm}$ in 1 and $281 \mathrm{pm}$ in 3) are of the same length (Table I), which means that the metal is located on the bisection of the N-P-N angle. The lithium atom in 1 is in the plane of the anion, while the potassium in 3 is $1.2 \mathrm{pm}$ out of the plane, possibly because of steric hindrance. In addition, the lithium atom in 1 is coordinated by two THF molecules whereas the potassium atom in 3 is coordinated by four THF molecules. This results in a much lower melting point of 3 , although the structures of 1 and 3 are very similar. 1 melts at $165^{\circ} \mathrm{C}$ whereas 3 decomposes at temperatures higher than $-20^{\circ} \mathrm{C}$. It is worthy to note that a close contact between the $\pi$-electron system of the phenyl ligand at the phosphorus and the potassium metal could not be observed in this molecule as in the potassium sufinamidinate. ${ }^{9}$

The most surprising structure in this series is the sodium sodiumate 2. In the sodium aminoiminophosphoranate, one sodium atom is coordinated by two anions and the cation is formed by the second sodium surrounded by six THF molecules. Obviously this arrangement is favorable to the $\left[\mathrm{Ph}_{2} \mathrm{P}\right.$ $\left(\mathrm{Me}_{3} \mathrm{SiN}\right)_{2} \mathrm{Na}$ (THF) ${ }_{3}$ ] monomeric molecule one might expect regarding the structures of 1 and 3 . Thus 2 is related to the lithium (sulfinamidinato)lithiate. ${ }^{14}$ As in the latter, the $P(1) \cdots \mathrm{Na}(1)$ and $P(2) \cdots \mathrm{Na}(1)$ vectors intersect at an angle of $174.2^{\circ}$, indicating that the anions try to maximize their distance. The $P(1) N(1) N(2) N a(1)$ and the $P(2) N(3) N(4) N a(1)$ planes are only twisted by $2.9^{\circ}$ from being perpendicular to each other. 
Table I. Selected Bond Lengths (pm) and Angles (deg) for 1-5

\begin{tabular}{|c|c|c|c|c|c|}
\hline & $1\left(\mathrm{M}=\mathrm{Li}^{\prime}\right)$ & $2(\mathrm{M}=\mathrm{Na})$ & $3(M=K)$ & $4(M=R b)$ & $5(M=C s)$ \\
\hline $\begin{array}{l}P(1)-N(1) \\
P(1)-N(2) \\
P(2)-N(3) \\
P(2)-N(4)\end{array}$ & $\begin{array}{l}157.9(4) \\
158.0(4)\end{array}$ & $\begin{array}{l}156.7(5) \\
157.5(7) \\
157.3(7) \\
157.6(6)\end{array}$ & $\begin{array}{l}156.7(6) \\
157.1(5)\end{array}$ & $\begin{array}{l}158.5(3) \\
156.7(4)\end{array}$ & $\begin{array}{l}157.5(1) \\
157.6(1)\end{array}$ \\
\hline $\begin{array}{l}\text { M.PP(1) } \\
\text { M.PP(2) }\end{array}$ & $252.0(9)$ & $\begin{array}{l}290.5(3) \\
291.4(3)\end{array}$ & $333.6(4)$ & $348.0(1)$ & $363.8(1)$ \\
\hline $\begin{array}{l}M-N(1) \\
M-N(2) \\
M-N(3) \\
M-N(4) \\
M-N(1 a)\end{array}$ & $\begin{array}{l}207.7(11) \\
204.4(9)\end{array}$ & $\begin{array}{l}242.4(7) \\
242.1(6) \\
238.9(6) \\
242.2(6)\end{array}$ & $\begin{array}{l}280.3(6) \\
281.9(6)\end{array}$ & $\begin{array}{l}291.7(4) \\
298.9(2)\end{array}$ & $\begin{array}{l}314.1(2) \\
301.0(2)\end{array}$ \\
\hline $\mathrm{M}-\mathrm{O}$ (av) & 192.9 & 236.6 & 273.5 & 287.1 & \\
\hline $\begin{array}{l}\text { M. . ring center }(\mathrm{C} 30 \mathrm{a}) \\
\mathrm{M} \cdots \text { - ring center }(\mathrm{C} 40)\end{array}$ & & & & 397.1 & $\begin{array}{l}338.5 \\
480.8\end{array}$ \\
\hline $\begin{array}{l}N(1)-P(1)-N(2) \\
N(3)-P(2)-N(4)\end{array}$ & $109.4(2)$ & $\begin{array}{l}112.8(3) \\
111.2(3)\end{array}$ & $114.1(3)$ & $113.7(2)$ & $113.7(1)$ \\
\hline $\begin{array}{l}\mathrm{P}(1)-\mathrm{N}(1)-\mathrm{Si}(1) \\
\mathrm{P}(1)-\mathrm{N}(2)-\mathrm{Si}(2) \\
\mathrm{P}(2)-\mathrm{N}(3)-\mathrm{Si}(3) \\
\mathrm{P}(2)-\mathrm{N}(4)-\mathrm{Si}(4)\end{array}$ & $\begin{array}{l}139.3(3) \\
142.8(3)\end{array}$ & $\begin{array}{l}140.3(4) \\
141.1(4) \\
146.2(4) \\
141.9(4)\end{array}$ & $\begin{array}{l}137.7(4) \\
138.1(4)\end{array}$ & $\begin{array}{l}139.2(2) \\
135.5(2)\end{array}$ & $\begin{array}{l}144.9(1) \\
137.5(1)\end{array}$ \\
\hline
\end{tabular}

Table II. Crystal Data for $\mathbf{1 5}$

\begin{tabular}{|c|c|c|c|c|c|}
\hline & $\mathbf{1}^{1}$ & 2 & 3 & 4 & 5 \\
\hline $\begin{array}{l}\text { formula } \\
\text { fw }\end{array}$ & $\begin{array}{l}\mathrm{C}_{26} \mathrm{H}_{44} \mathrm{LiN}_{2} \mathrm{O}_{2} \mathrm{PSi}_{2} \\
510.7\end{array}$ & $\begin{array}{l}\mathrm{C}_{64} \mathrm{H}_{112} \mathrm{~N}_{4} \mathrm{Na}_{2} \mathrm{O}_{7} \mathrm{P}_{2} \mathrm{Si}_{4} \\
1269.9\end{array}$ & $\begin{array}{l}\mathrm{C}_{34} \mathrm{H}_{60} \mathrm{KN}_{2} \mathrm{O}_{3} \mathrm{PSi}_{2} \\
687.1\end{array}$ & $\begin{array}{l}\mathrm{C}_{44} \mathrm{H}_{72} \mathrm{~N}_{4} \mathrm{O}_{2} \mathrm{P}_{2} \mathrm{Rb}_{2} \mathrm{Si}_{4} \\
1034.3\end{array}$ & $\begin{array}{l}\mathrm{C}_{36} \mathrm{H}_{56} \mathrm{Cs}_{2} \mathrm{~N}_{2} \mathrm{P}_{2} \mathrm{Si}_{4} \\
985.0\end{array}$ \\
\hline crystal size (mm) & $0.3 \times 0.3 \times 0.2$ & $0.4 \times 0.4 \times 0.1$ & $0.8 \times 0.5 \times 0.5$ & $0.3 \times 0.4 \times 0.5$ & $0.4 \times 0.3 \times 0.3$ \\
\hline space group & & $P 2_{1}$ & $C 2 / c$ & & $P 2_{1} / n$ \\
\hline$a(\mathrm{pm})$ & $1080.2(2)$ & $1347.3(2)$ & $3659(3)$ & $1118.3(3)$ & $1019.7(2)$ \\
\hline$b(\mathrm{pm})$ & $1035.7(2)$ & $1727.3(2)$ & $1095.7(4)$ & $1164.4(3)$ & $1215.6(2)$ \\
\hline$c(\mathrm{pm})$ & $1375.7(2)$ & $1818.8(2)$ & $2055.2(11)$ & $1297.7(3)$ & $1824.5(4)$ \\
\hline$\alpha(\mathrm{deg})$ & 90 & 90 & 90 & $66.584(8)$ & 90 \\
\hline$\beta(\mathrm{deg})$ & $94.78(2)$ & $105.39(2)$ & $94.54(5)$ & $88.618(12)$ & $98.06(2)$ \\
\hline$\gamma(\mathrm{deg})$ & 90 & 90 & 90 & $69.791(14)$ & 90 \\
\hline$V\left(\mathrm{~nm}^{3}\right)$ & 1.533 & 4.0809 & 8.214 & 1.377 & 2.240 \\
\hline$Z$ & 2 & 2 & 8 & 1 & 2 \\
\hline$\rho_{c}\left(\mathrm{Mgm}^{-3}\right)$ & 1.106 & 1.033 & 1.111 & 1.256 & 1.461 \\
\hline$\mu\left(\mathrm{mm}^{-1}\right)$ & 0.185 & 0.167 & 0.261 & 1.971 & 1.835 \\
\hline$F(000)$ & 552 & 1367 & 2976 & 540 & 922 \\
\hline $2 \theta$ range $(\mathrm{deg})$ & $8-50$ & $8-50$ & $8-48$ & $8-48$ & $8-60$ \\
\hline no. of measd reflns & 4036 & 14001 & 9581 & 4361 & 7138 \\
\hline no. of unique reflns & 3806 & 13511 & 6481 & 4273 & 6511 \\
\hline no. of obsd reflns & 2865 & 10376 & 4408 & 3589 & 5987 \\
\hline$p$ for $F>p \sigma(F)$ & 4 & 3 & 3 & 3 & 3 \\
\hline$R$ & 0.057 & 0.093 & 0.107 & 0.042 & 0.023 \\
\hline$R_{\mathrm{w}}$ & 0.055 & 0.103 & 0.128 & 0.048 & 0.030 \\
\hline goodness of fit & 1.28 & 2.04 & 2.51 & 1.70 & 1.69 \\
\hline weighting factor $g$ & 0.0005 & 0.001 & 0.001 & 0.0003 & 0.0001 \\
\hline refined parameters & 308 & 752 & 397 & 253 & 233 \\
\hline highest difference peak $\left(\mathrm{e} \mathrm{nm}^{-3}\right.$ ) & 320 & 1230 & 1370 & 570 & 430 \\
\hline$\eta$ & $1.3(5)$ & $1.1(3)$ & & & \\
\hline
\end{tabular}

The trimethylsilyl groups slot into each other like in a "molecular gear-wheel", leaving the central $\mathrm{Na}^{+}$covered with a hydrocarbon surface. As the sodium cation is covered with THF molecules, the whole material is quite soluble, even in nonpolar hydrocarbons.

We tried to confirm the two different sodium sites in solution and in the solid state by NMR techniques. We have detected only one, albeit broad, ${ }^{23} \mathrm{Na} \mathrm{NMR}$ signal in solution, even at -80 ${ }^{\circ} \mathrm{C}$, probably as a result of a fluxional process. In the solid state, we found a split ${ }^{23} \mathrm{Na}$ MAS NMR signal, but we could not exclude the fact that this was an effect of quadrupolar splitting. Furthermore, $\mathbf{2}$ has a very low decomposition point and the vapor pressure of the coordinated THF as well as the uncoordinated lattice THF is very low, so we cannot guarantee that the material in the solid-state rotor has the same modification as in the single crystal.

The two derivatives $\left[\mathrm{Ph}_{2} \mathrm{P}\left(\mathrm{Me}_{3} \mathrm{SiN}\right)_{2} \mathrm{Rb}(\mathrm{THF})\right]_{2}$ (4) and $\left[\mathrm{Ph}_{2} \mathrm{P}\left(\mathrm{Me}_{3} \mathrm{SiN}\right)_{2} \mathrm{Cs}\right]_{2}(5)$ are dimers in the solid state. 4 consists of three four-membered rings fused to a stair-shaped structure. The normal of the central $\mathrm{Rb}_{2} \mathrm{~N}_{2}$ ring intersects the normal of the $\mathrm{RbN}_{2} \mathrm{P}$ ring at an angle of $92.9^{\circ}$. Each rubidium of the dimer is coordinated by one additional THF molecule. The Rb- phenyl ring center distance is $397 \mathrm{pm}$, hence $27 \mathrm{pm}$ longer than in $\left[\mathrm{PhS}\left(\mathrm{Me}_{3} \mathrm{SiN}\right)_{2} \mathrm{Rb}(\mathrm{THF})\right]_{2}{ }_{2}$ and even $78.2 \mathrm{pm}$ longer than in $\mathrm{Ph}_{2} \mathrm{CPhRb}$ (PMDETA); ${ }^{18} \mathrm{PMDETA}=\left(\mathrm{Me}_{2} \mathrm{NCH}_{2} \mathrm{CH}_{2}\right)_{2} \mathrm{NMe}$. Therefore, the interaction between the $\pi$ system of the ligand and the metal in $\mathbf{4}$ is very weak. The opposite is the case in $\mathbf{5}$ (Figure 5). The distance between the ring center and the cesium metal is $338.5 \mathrm{pm}$, hence $16.6 \mathrm{pm}$ shorter than in $\left[\mathrm{PhS}\left(\mathrm{Me}_{3} \mathrm{SiN}\right)_{2-}\right.$ $\mathrm{Cs}(\mathrm{THF})]_{2}{ }^{9}$ and only $5 \mathrm{pm}$ longer than in $\mathrm{Ph}_{2} \mathrm{CPhCs}-$ (PMDETA). ${ }^{18}$ This seems remarkable because in the $\mathrm{Ph}_{2} \mathrm{P}(\mathrm{NSi}-$ $\left.\mathrm{Me}_{3}\right)_{2}$ - ion the negative charge is almost entirely located at the nitrogen atoms whereas in the $\mathrm{Ph}_{3} \mathrm{C}^{-}$ion it is almost entirely located in the coordinated phenyl ring. Nevertheless, the phenyl group in 5 is surprisingly attractive for the soft and easy to polarize cesium metal. The normal of the central $\mathrm{Cs}_{2} \mathrm{~N}_{2}$ ting intersects the normal of the $\mathrm{CsN}_{2} \mathrm{P}$ ring at an angle of $96.6^{\circ}$. Relatively weak interactions with a second phenyl group $(480.8 \mathrm{pm})$ and with a methyl group of another dimeric molecule lead to an overall

(18) Hoffmann, D.; Bauer, W.; Pieper, U.; Schleyer, P. v. R.; Stalke, D. Organometallics, in press. 
Table III. Atomic Coordinates $\left(\times 10^{4}\right)$ and Equivalent Isotropic Displacement Coefficients $\left(\mathrm{pm}^{2} \times 10^{-1}\right)$ for 2

\begin{tabular}{|c|c|c|c|c|c|c|c|c|c|}
\hline & $x$ & $y$ & $z$ & $U(\mathrm{eq})^{a}$ & & $x$ & $y$ & $z$ & $U(\mathrm{eq})^{a}$ \\
\hline $\mathrm{Na}(1)$ & $-1084(2)$ & 7559 & $-2257(2)$ & $46(1)$ & $C(84)$ & $-5012(8)$ & $5756(6)$ & $-3629(6)$ & $72(4)$ \\
\hline$P(1)$ & $1064(1)$ & $7561(2)$ & $-2277(1)$ & $35(1)$ & $C(85)$ & $-4212(6)$ & $6123(5)$ & $-3099(4)$ & $52(3)$ \\
\hline $\mathbf{N}(1)$ & $188(4)$ & $7165(4)$ & $-2907(3)$ & $40(2)$ & $\mathrm{Na}(2)$ & $-7112(2)$ & $2430(2)$ & $-2787(2)$ & $41(1)$ \\
\hline $\operatorname{Si}(1)$ & $-13(2)$ & $6388(2)$ & $-3476(1)$ & $51(1)$ & $O(1)$ & $-8519(4)$ & $1591(3)$ & $-3203(3)$ & $55(2)$ \\
\hline$C(11)$ & $708(8)$ & $6448(7)$ & $-4225(6)$ & $87(5)$ & $C(16)$ & $-9440(8)$ & $1617(7)$ & $-2946(6)$ & $83(4)$ \\
\hline$C(12)$ & $-1421(7)$ & $6321(7)$ & $-3979(6)$ & $90(5)$ & $C(17)$ & $-10217(7)$ & $1132(6)$ & $-3502(7)$ & $89(5)$ \\
\hline$C(13)$ & $346(7)$ & $5466(5)$ & $-2954(6)$ & $71(4)$ & $C(18)$ & $-9519(7)$ & $529(6)$ & $-3713(6)$ & $77(4)$ \\
\hline $\mathrm{N}(2)$ & $645(4)$ & $8012(4)$ & $-1670(4)$ & $42(2)$ & $C(19)$ & $-8601(7)$ & $974(6)$ & $-3713(6)$ & $79(4)$ \\
\hline $\operatorname{Si}(2)$ & $949(2)$ & $8747(2)$ & $-1050(1)$ & $50(1)$ & $O(2)$ & $-6247(4)$ & $1877(3)$ & $-3649(3)$ & $55(2)$ \\
\hline$C(21)$ & $-141(9)$ & $8875(6)$ & $-600(7)$ & $100(5)$ & $C(26)$ & $-5628(9)$ & $1183(7)$ & $-3549(7)$ & $96(5)$ \\
\hline$C(22)$ & $1060(7)$ & $9692(5)$ & $-1516(6)$ & $74(4)$ & $C(27)$ & $-5778(22)$ & $929(10)$ & $-4393(12)$ & $90(9)$ \\
\hline$C(23)$ & $2202(8)$ & $8622(6)$ & $-309(6)$ & $88(5)$ & $C\left(27^{\prime}\right)$ & $-4980(34)$ & $1324(36)$ & $-4154(18)$ & $112(23)$ \\
\hline$C(50)$ & $2014(5)$ & $6839(4)$ & $-1811(4)$ & $39(2)$ & $C(28)$ & $-5733(10)$ & $1723(9)$ & $-4788(8)$ & $114(7)$ \\
\hline$C(51)$ & $2727(5)$ & $6522(5)$ & $-2158(5)$ & $50(3)$ & $C(29)$ & $-6249(9)$ & $2232(7)$ & $-4352(6)$ & $86(5)$ \\
\hline$C(52)$ & $3373(5)$ & $5912(5)$ & $-1820(5)$ & $51(3)$ & $O(3)$ & $-5698(4)$ & $3285(3)$ & $-2398(3)$ & $53(2)$ \\
\hline$C(53)$ & $3335(7)$ & $5626(5)$ & $-1145(5)$ & $62(4)$ & $C(36)$ & $-5587(9)$ & $3774(8)$ & $-1791(7)$ & $108(6)$ \\
\hline$C(54)$ & $2627(7)$ & $5931(6)$ & $-796(5)$ & $66(4)$ & $C(37)$ & $-4574(12)$ & $4019(11)$ & $-1520(10)$ & $145(6)$ \\
\hline$C(55)$ & $1984(6)$ & $6525(5)$ & $-1107(4)$ & $51(3)$ & $C(38)$ & $-4094(16)$ & $3717(13)$ & $-1916(11)$ & $189(8)$ \\
\hline$C(60)$ & $1828(5)$ & $8175(4)$ & $-2744(5)$ & $42(3)$ & $C(39)$ & $-4758(9)$ & $3270(8)$ & $-2605(8)$ & $105(6)$ \\
\hline$C(61)$ & $2802(5)$ & $8447(5)$ & $-2327(5)$ & $55(3)$ & $O(4)$ & $-6261(4)$ & $1543(3)$ & $-1842(3)$ & $57(2)$ \\
\hline$C(62)$ & $3386(7)$ & $8901(5)$ & $-2677(7)$ & $65(4)$ & $C(46)$ & $-6664(10)$ & $852(8)$ & $-1642(10)$ & $127(7)$ \\
\hline$C(63)$ & $3002(9)$ & $9078(5)$ & $-3437(8)$ & $82(5)$ & $C(47)$ & $-5920(11)$ & $442(8)$ & $-1081(8)$ & $117(6)$ \\
\hline$C(64)$ & $2034(9)$ & $8824(6)$ & $-3860(7)$ & $84(5)$ & $C(48)$ & $-5075(14)$ & $875(10)$ & $-947(12)$ & $167(7)$ \\
\hline $\mathrm{C}(65)$ & $1469(6)$ & $8376(5)$ & $-3492(5)$ & $60(3)$ & $C(49)$ & $-5278(11)$ & $1642(8)$ & $-1316(9)$ & $144(7)$ \\
\hline$P(2)$ & $-3224(1)$ & $7387(2)$ & $-2226(1)$ & $37(1)$ & $O(5)$ & $-7949(5)$ & $2992(4)$ & $-1928(3)$ & $64(2)$ \\
\hline$N(3)$ & $-2793(4)$ & $8070(3)$ & $-2623(3)$ & $41(2)$ & $C(56)$ & $-7890(10)$ & $2685(9)$ & $-1194(7)$ & $120(7)$ \\
\hline $\mathrm{Si}(3)$ & $-3079(1)$ & $8854(2)$ & $-3178(1)$ & $44(1)$ & $C(57)$ & $-8631(16)$ & $3183(13)$ & $-893(14)$ & $210(9)$ \\
\hline$C(31)$ & $-3783(9)$ & $9612(6)$ & $-2773(7)$ & $89(5)$ & $\mathrm{C}(58)$ & $-8879(15)$ & $3849(11)$ & $-1396(9)$ & $157(6)$ \\
\hline$C(32)$ & $-1834(7)$ & $9279(6)$ & $-3257(6)$ & $73(4)$ & $C(59)$ & $-8471(12)$ & $3742(8)$ & $-2044(9)$ & $139(8)$ \\
\hline$C(33)$ & $-3863(9)$ & $8668(8)$ & $-4155(6)$ & $104(5)$ & $\mathrm{O}(6)$ & $-7918(4)$ & $3362(4)$ & $-3711(3)$ & $65(2)$ \\
\hline$N(4)$ & $-2350(4)$ & $6789(3)$ & $-1856(3)$ & $38(2)$ & $C(66)$ & $-7505(9)$ & $4112(6)$ & $-3861(7)$ & $100(5)$ \\
\hline $\mathrm{Si}(4)$ & $-2021(2)$ & $6130(2)$ & $-1159(2)$ & $52(1)$ & $C(67)$ & $-8089(9)$ & $4403(8)$ & $-4592(7)$ & $101(5)$ \\
\hline$C(41)$ & $-1673(12)$ & $5182(7)$ & $-1547(8)$ & $131(7)$ & $C(68)$ & $-9007(10)$ & $3859(8)$ & $-4783(8)$ & $138(6)$ \\
\hline$C(42)$ & $-814(13)$ & $6369(10)$ & $-473(9)$ & $218(10)$ & $C(69)$ & $-8888(9)$ & $3271(7)$ & $-4292(9)$ & $121(6)$ \\
\hline$C(43)$ & $-2987(11)$ & $5897(8)$ & $-644(9)$ & $134(7)$ & $O(7)$ & $-1504(14)$ & $3145(16)$ & $-3758(16)$ & $93(10)$ \\
\hline$C(70)$ & $-3831(5)$ & $7783(4)$ & $-1521(4)$ & $42(3)$ & $C(76)$ & $-2244(27)$ & $2851(13)$ & $-4171(16)$ & $122(15)$ \\
\hline$C(71)$ & $-4669(5)$ & $7435(6)$ & $-1340(5)$ & $59(3)$ & $C(77)$ & $-3193(14)$ & $3338(18)$ & $-4347(14)$ & $104(11)$ \\
\hline$C(72)$ & $-5087(6)$ & $7738(7)$ & $-782(5)$ & $65(4)$ & $C(78)$ & $-2799(23)$ & $4051(14)$ & $-3981(16)$ & $112(13)$ \\
\hline$C(73)$ & $-4714(7)$ & $8376(8)$ & $-418(5)$ & $75(4)$ & $C(79)$ & $-1786(23)$ & $3824(22)$ & $-3620(20)$ & $164(19)$ \\
\hline$C(74)$ & $-3860(8)$ & $8755(6)$ & $-576(5)$ & $77(4)$ & $O\left(7^{\prime}\right)$ & $-1786(19)$ & $1001(14)$ & $-1129(12)$ & $217(12)$ \\
\hline$C(75)$ & $-3446(6)$ & $8444(6)$ & $-1124(5)$ & $62(3)$ & $C\left(76^{\prime}\right)$ & $-1218(14)$ & $1205(13)$ & $-1646(14)$ & $116(8)$ \\
\hline$C(80)$ & $-4299(5)$ & $6892(4)$ & $-2892(4)$ & $39(2)$ & $C\left(77^{\prime}\right)$ & $-1943(21)$ & $1541(16)$ & $-2362(11)$ & $187(15)$ \\
\hline$C(81)$ & $-5206(5)$ & $7280(5)$ & $-3211(4)$ & $48(3)$ & $C\left(78^{\prime}\right)$ & $-2811(16)$ & $1853(14)$ & $-2059(15)$ & $125(9)$ \\
\hline$C(82)$ & $-6026(6)$ & $6906(6)$ & $-3745(5)$ & $60(3)$ & $C\left(79^{\prime}\right)$ & $-2441(19)$ & $1646(17)$ & $-1218(13)$ & $175(14)$ \\
\hline
\end{tabular}

${ }^{a} U(\mathrm{eq})$ is defined as one-third of the trace of the orthogonalized $U_{i j}$ tensor

polymeric structure. Although synthesis and crystallization were carried out in THF, no donor molecule is present in the solid state.

\section{Conclusion}

Compared to the series of alkali metal sufinamidinates, the series of alkali metal aminoiminophosphoranates presented here does structurally not seem to be so homogeneous as the first. Surprisingly, the sodium derivative forms a sodium-sodiumate structure, whereas the cesium derivative forms a polymer with a remarkably close intramolecular metal $-\pi$ electron contact. This distance is as close as the one to the $\pi$ system of the $\mathrm{Ph}_{3} \mathrm{C}^{-}$anion exclusively containing carbon atoms.

\section{Experimental Section}

All manipulations were performed under an inert atmosphere of dry argon gas with Schlenk techniques or in an argon glovebox. The $n$-hexane, diethyl ether, and THF solvents were dried over $\mathrm{Na} / \mathrm{K}$ alloy and distilled prior to use.

NMR spectra were obtained with a Bruker MSL 400 or AM 250 instrument. All NMR spectra were recorded in toluene- $d_{8}$ or benzene- $d_{6}$ with $\mathrm{SiMe}_{4}, \mathrm{H}_{3} \mathrm{PO}_{4}, \mathrm{LiCl}, \mathrm{NaCl}$, or $\mathrm{CsCl}$ as external standard.

$\left[\mathbf{P h}_{2} \mathbf{P}\left(\mathrm{Me}_{3} \mathrm{SiN}\right)_{2} \mathrm{Li}(\mathrm{THF})_{2}\right]$ (1)..$^{2,11-13}$ A solution of $10 \mathrm{~mL}$ of $n$-butyllithium in hexane $(1.6 \mathrm{M} ; 16 \mathrm{mmol})$ was added to $5.8 \mathrm{~g}$ of diphenyl((trimethylsilyl)amino)((trimethylsilyl)imino)phosphorane (16 $\mathrm{mmol}$ ) in $30 \mathrm{~mL}$ of diethyl ether over a period of $1 / 2 \mathrm{~h}$ at room temperature. The mixture was refluxed for $1 \mathrm{~h}$ and the ether removed under reduced pressure. A $20-\mathrm{mL}$ portion of THF was added, and the mixture was again refluxed for $1 \mathrm{~h}$. After a few days at $-22^{\circ} \mathrm{C}$, colorless crystals were obtained. Mp: $165{ }^{\circ} \mathrm{C}$. NMR: ${ }^{1} \mathrm{H}\left(\mathrm{C}_{6} \mathrm{D}_{6}\right) \delta 0.153\left(\mathrm{Me}_{3} \mathrm{Si}\right), 1.389$, 3.633 (THF), 7.0-8.0 (Ph); ${ }^{7 \mathrm{Li}}\left(\mathrm{C}_{6} \mathrm{D}_{6}\right) \delta 0.560 ;{ }^{31} \mathrm{P}\left(\mathrm{C}_{6} \mathrm{D}_{6}\right) \delta 7.444$.

[Na(THF) $)_{6}\left[\mathrm{Na}\left\{\left(\mathrm{NSiMe}_{3}\right)_{2} \mathrm{PPh}_{2}\right\}_{2}\right]$ (2). To a suspension of $0.6 \mathrm{~g}$ of $\mathrm{NaH}(25 \mathrm{mmol})$ in $20 \mathrm{~mL}$ of dry THF was added $7.5 \mathrm{~g}$ of diphenyl((trimethylsilyl)amino) ((trimethylsilyl)imino) phosphorane $(20 \mathrm{mmol})$ in $20 \mathrm{~mL}$ of THF over a period of $1 / 2 \mathrm{~h}$. The reaction mixture was refluxed for $1 \mathrm{~h}$. The remaining $\mathrm{NaH}$ was filtered off from the cold mixture and the volume reduced to the half. Colorless crystals were obtained at -35 ${ }^{\circ} \mathrm{C}$ after several days. Mp: $\leq-20^{\circ} \mathrm{C}$ dec. NMR: ${ }^{\prime} \mathrm{H}\left(\mathrm{C}_{7} \mathrm{D}_{8}\right) \delta 0.078$ ( $\mathrm{Me}{ }_{3} \mathrm{Si}$ ), 1.392, 3.439 (THF), 6.8-7.9 (Ph); ${ }^{23} \mathrm{Na}\left(\mathrm{C}_{7} \mathrm{D}_{8}\right) \delta 13.1$ (broad signal); ${ }^{3 !} \mathrm{P}\left(\mathrm{C}_{7} \mathrm{D}_{8}\right) \delta 8.650$.

$\left[\mathrm{Ph}_{2} \mathrm{P}\left(\mathrm{Me}_{3} \mathrm{SiN}\right)_{2} \mathrm{~K}(\mathrm{THF})_{4}\right]$ (3). To a suspension of $1 \mathrm{~g}$ of potassium hydride $(25 \mathrm{mmol})$ in $20 \mathrm{~mL}$ of THF was added $7.5 \mathrm{~g}$ of diphenyl((trimethylsilyl)amino)((trimethylsilyl)imino)phosphorane $(20 \mathrm{mmol})$ in $20 \mathrm{~mL}$ THF over a period of $1 / 2 \mathrm{~h}$. The reaction mixture was refluxed for $1 \mathrm{~h}$. The remaining $\mathrm{KH}$ was filtered off from the cold mixture and the volume reduced to the half. After several days at $-35^{\circ} \mathrm{C}$ colorless crystals were obtained. $\mathrm{Mp}: \leq-20^{\circ} \mathrm{C}$ dec. NMR: ${ }^{\prime} \mathrm{H}\left(\mathrm{C}_{7} \mathrm{D}_{8}\right) \delta 0.03$ ( $\left.\mathrm{Me}_{3} \mathrm{Si}\right), 1.435,3.50$ (THF), 7.1-7.8 (Ph); ${ }^{31} \mathrm{P}\left(\mathrm{C}_{7} \mathrm{D}_{8}\right) \delta 4.08$.

$\left[\mathbf{P h}_{2} \mathbf{P}\left(\mathrm{Me}_{3} \mathrm{SiN}_{2}{ }_{2} \mathbf{R b}(\mathrm{THF})\right]_{2}\right.$ (4). A 1 -g sample of elemental rubidium (11.8 mmol) was suspended in $20 \mathrm{~mL}$ of THF. To this suspension was added $4.3 \mathrm{~g}$ of diphenyl((trimethylsilyl)amino)((trimethylsilyl)imino)phosphorane $(11.8 \mathrm{mmol}$ ) in $20 \mathrm{~mL}$ hexane over a period of $1 / 2 \mathrm{~h}$ at 50 ${ }^{\circ} \mathrm{C}$. After being stirred for $1 \mathrm{~h}$ at this temperature, the cold solution was filtered off. Colorless crystals were obtained at $-35^{\circ} \mathrm{C}$ after several days. Mp: $95^{\circ} \mathrm{C}$. NMR: ${ }^{1} \mathrm{H}\left(\mathrm{C}_{6} \mathrm{D}_{6}\right) \delta 0.855\left(\mathrm{Me}_{3} \mathrm{Si}\right), 1.404,3.515$ (THF), 7.0-8.0 (Ph); ${ }^{31} \mathrm{P}\left(\mathrm{C}_{6} \mathrm{D}_{6}\right) \delta 3.194$.

$\left[\mathrm{Ph}_{2} \mathbf{P}\left(\mathrm{Me}_{3} \mathrm{SiN}\right)_{2} \mathrm{Cs}\right]_{2}(5)$. A 1 -g sample of elemental cesium $(7.5 \mathrm{mmol})$ was suspended in $20 \mathrm{~mL}$ of THF. To this suspension was added $2.7 \mathrm{~g}$ 
Table IV. Atomic Coordinates $\left(\times 10^{4}\right)$ and Equivalent Isotropic Displacement Coefficients $\left(\mathrm{pm}^{2} \times 10^{-1}\right)$ for 3

\begin{tabular}{|c|c|c|c|c|}
\hline & $x$ & $y$ & $z$ & $U(\text { eq })^{a}$ \\
\hline $\mathbf{K}(1)$ & $3767(1)$ & $3104(2)$ & $2075(1)$ & $57(1)$ \\
\hline$P(1)$ & $3765(1)$ & $1418(2)$ & $723(1)$ & 41(1) \\
\hline $\mathrm{N}(1)$ & $3475(1)$ & $1268(5)$ & $1239(3)$ & $50(2)$ \\
\hline $\operatorname{Si}(1)$ & $3162(1)$ & $234(3)$ & $1429(1)$ & $67(1)$ \\
\hline$C(11)$ & $2868(2)$ & $-384(10)$ & $734(4)$ & $89(4)$ \\
\hline$C(12)$ & $2842(3)$ & $964(15)$ & $1963(5)$ & $151(7)$ \\
\hline$C(13)$ & $3376(3)$ & $-1086(12)$ & $1861(7)$ & $145(6)$ \\
\hline $\mathrm{N}(2)$ & $4050(1)$ & $2469(5)$ & $884(3)$ & $44(2)$ \\
\hline $\operatorname{Si}(2)$ & $4346(1)$ & $3303(2)$ & $492(1)$ & $46(1)$ \\
\hline$C(21)$ & $4643(2)$ & $4159(8)$ & $1106(4)$ & $73(3)$ \\
\hline$C(22)$ & $4656(2)$ & $2420(8)$ & $-16(4)$ & $74(3)$ \\
\hline $\mathrm{C}(23)$ & $4114(2)$ & $4435(7)$ & $-73(4)$ & $67(3)$ \\
\hline$C(30)$ & $3530(2)$ & $1657(6)$ & $-83(3)$ & $48(2)$ \\
\hline$C(31)$ & $3678(2)$ & $1381(9)$ & $-656(3)$ & $74(3)$ \\
\hline$C(32)$ & $3488(3)$ & $1664(11)$ & $-1258(4)$ & $98(5)$ \\
\hline$C(33)$ & $3156(3)$ & $2188(10)$ & $-1297(4)$ & $90(4)$ \\
\hline$C(34)$ & $3005(3)$ & $2485(9)$ & $-734(5)$ & $88(4)$ \\
\hline$C(35)$ & $3186(2)$ & $2224(7)$ & $-122(4)$ & $63(3)$ \\
\hline$C(40)$ & $4004(2)$ & $-39(6)$ & $630(3)$ & $45(2)$ \\
\hline$C(41)$ & $3844(2)$ & $-1030(7)$ & $321(4)$ & $67(3)$ \\
\hline$C(42)$ & $4022(2)$ & $-2131(7)$ & $303(5)$ & $69(3)$ \\
\hline$C(43)$ & $4367(2)$ & $-2267(7)$ & $583(4)$ & $65(3)$ \\
\hline$C(44)$ & $4538(2)$ & $-1301(7)$ & $873(4)$ & $72(3)$ \\
\hline$C(45)$ & $4364(2)$ & $-179(6)$ & $900(4)$ & $56(3)$ \\
\hline$O(1)$ & $4282(3)$ & $1946(9)$ & $2882(4)$ & $166(5)$ \\
\hline$C(51)$ & $4438(9)$ & $1001(28)$ & $2684(11)$ & $317(17)$ \\
\hline$C(52)$ & $4598(7)$ & $324(19)$ & $3248(12)$ & $271(14)$ \\
\hline$C(53)$ & $4529(4)$ & $839(17)$ & $3806(9)$ & $151(8)$ \\
\hline$C(54)$ & $4334(7)$ & $1968(15)$ & $3609(7)$ & $205(10)$ \\
\hline$O(2)$ & $3403(2)$ & $3112(8)$ & $3194(3)$ & $110(3)$ \\
\hline$C(61)$ & $3201(5)$ & $2393(16)$ & $3579(6)$ & $191(9)$ \\
\hline$C(62)$ & $3106(2)$ & $2924(13)$ & $4153(5)$ & $112(5)$ \\
\hline$C(63)$ & $3184(3)$ & $4220(12)$ & $4025(6)$ & $110(5)$ \\
\hline$C(64)$ & $3446(3)$ & $4232(11)$ & $3520(5)$ & $108(5)$ \\
\hline$O(3)$ & $3259(2)$ & $4824(5)$ & $1663(3)$ & $81(2)$ \\
\hline$C(71)$ & $3242(3)$ & $5240(11)$ & $1002(4)$ & $95(4)$ \\
\hline$C(72)$ & $2859(3)$ & $5404(18)$ & $810(6)$ & $151(8)$ \\
\hline$C(73)$ & $2671(3)$ & $5321(19)$ & $1362(8)$ & $173(9)$ \\
\hline$C(74)$ & $2915(4)$ & $4892(18)$ & $1873(7)$ & $176(9)$ \\
\hline$O(4)$ & $4131(2)$ & $5144(5)$ & $2540(3)$ & $78(2)$ \\
\hline$C(81)$ & $4449(2)$ & $5251(9)$ & $2998(5)$ & $84(4)$ \\
\hline$C(82)$ & $4524(4)$ & $6526(12)$ & $3055(7)$ & $149(7)$ \\
\hline$C(83)$ & $4326(5)$ & $7136(11)$ & $2549(9)$ & $163(8)$ \\
\hline$C(84)$ & $4023(3)$ & $6311(9)$ & $2320(6)$ & $109(5)$ \\
\hline
\end{tabular}

${ }^{a} U(\mathrm{eq})$ is defined as one-third of the trace of the orthogonalized $\mathbf{U}_{i j}$ tensor.

of diphenyl((trimethylsilyl)amino)((trimethylsilyl)amino)phosphorane $(7.5 \mathrm{mmol}$ ) in $20 \mathrm{~mL}$ of $n$-hexane over $1 / 2 \mathrm{~h}$. The reaction mixture was refluxed for $1 \mathrm{~h}$, and overnight a crop of colorless crystals was obtained. Mp: $203{ }^{\circ} \mathrm{C}$ dec. NMR: ${ }^{1} \mathrm{H}\left(\mathrm{C}_{7} \mathrm{D}_{8}\right) \delta 0.065\left(\mathrm{Me}_{3} \mathrm{Si},{ }^{4} \mathrm{~J}(\mathrm{H}, \mathrm{P})=0.34\right.$ $\mathrm{Hz}), 7.1-7.9(\mathrm{Ph}) ;{ }^{29} \mathrm{Si}\left(\mathrm{C}_{7} \mathrm{D}_{8}\right)-18.75\left({ }^{2} \mathrm{~J}(\mathrm{Si}, \mathrm{P})=22.8 \mathrm{~Hz}\right) ;{ }^{31} \mathrm{P}\left(\mathrm{C}_{7} \mathrm{D}_{8}\right)$ $\delta 1.53 ;{ }^{133} \mathrm{Cs}\left(\mathrm{C}_{7} \mathrm{D}_{8}\right) \delta 101.7$.

\section{$X$-ray Measurements of 1-5}

The intensities for all structures were collected on a StoeSiemens AED with graphite-monochromated Mo K $\alpha$ radiation $(\lambda=71.073 \mathrm{pm})$. Data were collected from oil-coated rapidlycooled crystals at $-120^{\circ} \mathrm{C}$ with a profile-fitted method. ${ }^{19}$ The structures were solved by direct methods or Patterson methods with SHELXS-90. ${ }^{20}$ All structures were refined by full-matrix least-squares procedures using SHELXTL-Plus, PC version. ${ }^{21} \mathrm{~A}$ riding model was employed to refine the hydrogen atom positions. The data for 2, 4, and 5 were corrected for absorption by a semiempirical method. The structures of 2-4 contain disordered THF molecules. In 2 and 4 , most of the disordered atom positions could be refined. Selected bond lengths and angles are shown in Table I, relevant crystallographic data for structures 2-5 in Table II, and fractional coordinates of $\mathbf{2}$ in Table III, of $\mathbf{3}$ in Table IV, of $\mathbf{4}$ in Table V, and of 5 in Table VI.

Acknowledgment. We wish to thank the Deutsche For-

(19) Clegg, W. Acta Crystallogr. 1981, A37, 22

(20) Sheldrick G. M Acta Crystallogr 1990, A46, 467

(21) By G. M. Sheldrick University of Göttingen, 1986.
Table V. Atomic Coordinates $\left(\times 10^{4}\right)$ and Equivalent Isotropic Displacement Coefficients $\left(\mathrm{pm}^{2} \times 10^{-1}\right)$ for 4

\begin{tabular}{|c|c|c|c|c|}
\hline & $x$ & $y$ & $z$ & $U(\text { eq })^{a}$ \\
\hline $\mathrm{Rb}(1)$ & $1518(1)$ & $21(1)$ & $4177(1)$ & $41(1)$ \\
\hline$P(1)$ & $-1848(1)$ & $2046(1)$ & $2780(1)$ & $30(1)$ \\
\hline Si(1) & $-1039(1)$ & $-1032(1)$ & $3298(1)$ & $37(1)$ \\
\hline $\mathrm{Si}(2)$ & $-991(1)$ & $4283(1)$ & $2378(1)$ & $47(1)$ \\
\hline$N(1)$ & $-1113(3)$ & $369(3)$ & $3443(2)$ & $33(1)$ \\
\hline $\mathrm{N}(2)$ & $-1056(3)$ & $2744(3)$ & $3055(3)$ & $35(1)$ \\
\hline$C(11)$ & $-1836(5)$ & $-642(4)$ & $1868(4)$ & $54(2)$ \\
\hline $\mathrm{C}(12)$ & $778(4)$ & $-2394(4)$ & $3590(4)$ & $57(2)$ \\
\hline$C(13)$ & $-1875(4)$ & $-1896(4)$ & $4388(4)$ & $50(2)$ \\
\hline$C(21)$ & $702(5)$ & $3934(6)$ & $1962(5)$ & $85(4)$ \\
\hline$C(22)$ & $-2309(5)$ & $5646(4)$ & $1044(4)$ & $63(3)$ \\
\hline$C(23)$ & $-1221(6)$ & $5188(5)$ & $3333(4)$ & $71(3)$ \\
\hline$C(30)$ & $-3535(4)$ & $2721(4)$ & $3164(3)$ & $35(2)$ \\
\hline$C(31)$ & $-3988(4)$ & $3782(4)$ & $3531(3)$ & $43(2)$ \\
\hline$C(32)$ & $-5240(4)$ & $4228(5)$ & $3885(4)$ & $57(2)$ \\
\hline$C(33)$ & $-6024(5)$ & $3610(5)$ & $3882(4)$ & $65(3)$ \\
\hline$C(34)$ & $-5592(4)$ & $2545(5)$ & $3532(5)$ & $66(3)$ \\
\hline$C(35)$ & $-4357(4)$ & $2098(4)$ & $3176(4)$ & $53(2)$ \\
\hline $\mathrm{C}(40)$ & $-2173(4)$ & $2571(4)$ & $1252(3)$ & $38(2)$ \\
\hline$C(41)$ & $-3426(4)$ & $3290(4)$ & $560(3)$ & $48(2)$ \\
\hline$C(42)$ & $-3542(5)$ & $3638(5)$ & $-612(4)$ & 69(3) \\
\hline$C(43)$ & $-2399(6)$ & $3250(5)$ & $-1077(4)$ & $74(3)$ \\
\hline$C(45)$ & $-1016(4)$ & $2206(4)$ & $745(3)$ & $50(2)$ \\
\hline$C(44)$ & $-1133(5)$ & $2525(5)$ & $-404(4)$ & $67(3)$ \\
\hline$O(1)$ & $3065(7)$ & $-378(8)$ & $2500(6)$ & $72(2)$ \\
\hline$O\left(1^{\prime}\right)$ & $3629(9)$ & $-91(9)$ & $2770(7)$ & $89(2)$ \\
\hline$C(51)$ & $2844(13)$ & $-51(14)$ & $1309(11)$ & $86(3)$ \\
\hline$C\left(51^{\prime}\right)$ & $3314(15)$ & $723(16)$ & $1589(14)$ & $110(4)$ \\
\hline$C(52)$ & $3925(15)$ & $-366(16)$ & $1014(13)$ & $212(5)$ \\
\hline$C(53)$ & $5164(16)$ & $-1512(16)$ & $2045(13)$ & $102(4)$ \\
\hline$C\left(53^{\prime}\right)$ & $4508(20)$ & $-1739(20)$ & $1923(17)$ & $129(6)$ \\
\hline$C(54)$ & $4662(15)$ & $-1126(17)$ & $2974(13)$ & $96(4)$ \\
\hline$C\left(54^{\prime}\right)$ & $4448(16)$ & $-1667(17)$ & $2966(14)$ & $104(5)$ \\
\hline
\end{tabular}

Table VI. Atomic Coordinates $\left(\times 10^{4}\right)$ and Equivalent Isotropic Displacement Coefficients $\left(\mathrm{pm}^{2} \times 10^{-1}\right)$ for 5

\begin{tabular}{lrrrr}
\hline & \multicolumn{1}{c}{$x$} & \multicolumn{1}{c}{$y$} & \multicolumn{1}{c}{$z$} & $U(\mathrm{eq})^{a}$ \\
\hline $\mathrm{Cs}(1)$ & $6702(1)$ & $-982(1)$ & $-327(1)$ & $29(1)$ \\
$\mathrm{P}(1)$ & $7195(1)$ & $1787(1)$ & $417(1)$ & $18(1)$ \\
$\mathrm{N}(1)$ & $6817(1)$ & $814(1)$ & $918(1)$ & $23(1)$ \\
$\mathrm{Si}(1)$ & $6760(1)$ & $402(1)$ & $1794(1)$ & $24(1)$ \\
$\mathrm{C}(11)$ & $5570(3)$ & $1182(2)$ & $2300(2)$ & $53(1)$ \\
$\mathrm{C}(12)$ & $8369(2)$ & $433(2)$ & $2435(1)$ & $53(1)$ \\
$\mathrm{C}(13)$ & $6179(3)$ & $-1056(2)$ & $1771(1)$ & $47(1)$ \\
$\mathrm{N}(2)$ & $7394(1)$ & $1420(1)$ & $-388(1)$ & $22(1)$ \\
$\mathrm{Si}(2)$ & $8253(1)$ & $1848(1)$ & $-1055(1)$ & $24(1)$ \\
$\mathrm{C}(21)$ & $7695(2)$ & $3210(2)$ & $-1476(1)$ & $39(1)$ \\
$\mathrm{C}(22)$ & $8027(2)$ & $802(2)$ & $-1822(1)$ & $38(1)$ \\
$\mathrm{C}(23)$ & $10087(2)$ & $1940(2)$ & $-745(1)$ & $46(1)$ \\
$\mathrm{C}(30)$ & $5871(1)$ & $2816(1)$ & $363(1)$ & $20(1)$ \\
$\mathrm{C}(31)$ & $5091(2)$ & $3059(1)$ & $-309(1)$ & $24(1)$ \\
$\mathrm{C}(32)$ & $3954(2)$ & $3705(2)$ & $-330(1)$ & $30(1)$ \\
$\mathrm{C}(33)$ & $3605(2)$ & $4131(2)$ & $314(1)$ & $32(1)$ \\
$\mathrm{C}(34)$ & $4404(2)$ & $3942(1)$ & $985(1)$ & $31(1)$ \\
$\mathrm{C}(35)$ & $5525(2)$ & $3290(1)$ & $1008(1)$ & $26(1)$ \\
$\mathrm{C}(40)$ & $8640(2)$ & $2567(1)$ & $840(1)$ & $21(1)$ \\
$\mathrm{C}(41)$ & $9745(2)$ & $2019(2)$ & $1208(1)$ & $29(1)$ \\
$\mathrm{C}(42)$ & $10890(2)$ & $2603(2)$ & $1480(1)$ & $37(1)$ \\
$\mathrm{C}(43)$ & $10950(2)$ & $3726(2)$ & $1375(1)$ & $36(1)$ \\
$\mathrm{C}(44)$ & $9867(2)$ & $4282(2)$ & $1008(1)$ & $35(1)$ \\
$\mathrm{C}(45)$ & $8720(2)$ & $3697(2)$ & $746(1)$ & $28(1)$
\end{tabular}

${ }^{a} U($ eq $)$ is defined as one-third of the trace of the orthogonalized $\mathbf{U}_{i j}$ tensor.

schungsgesellschaft and the Fonds der Chemischen Industrie for operating grants. Both authors are grateful to Dr. João Rocha, University of Cambridge, U.K., for recording the ${ }^{23} \mathrm{Na}$ MAS spectrum and to the Riedel-de Haën AG (Seelze) for supplying the polyfluoro polyether products for crystal application.

Supplementary Material Available: Tables of crystal and diffractometer data, bond lengths, bond angles, anisotropic displacement parameters, and $\mathrm{H}$ atom coordinates and isotropic displacement parameters (28 pages). Ordering information is given on any current masthead page. 